\title{
What Does General Secretary Xi Jinping Dream About?
}

\section{Citation}

Saich, Tony. "What does general secretary Xi Jinping dream about?" Ash Center Occasional Papers Series, Harvard University, Cambridge, MA, 2017.

\section{Published Version}

https://ash.harvard.edu/ash-publications

\section{Permanent link}

http://nrs.harvard.edu/urn-3:HUL.InstRepos:42367427

\section{Terms of Use}

This article was downloaded from Harvard University's DASH repository, and is made available under the terms and conditions applicable to Other Posted Material, as set forth at http:// nrs.harvard.edu/urn-3:HUL.InstRepos:dash.current.terms-of-use\#LAA

\section{Share Your Story}

The Harvard community has made this article openly available.

Please share how this access benefits you. Submit a story.

\section{Accessibility}


ASH CEN for Democratic Governance and Innovation

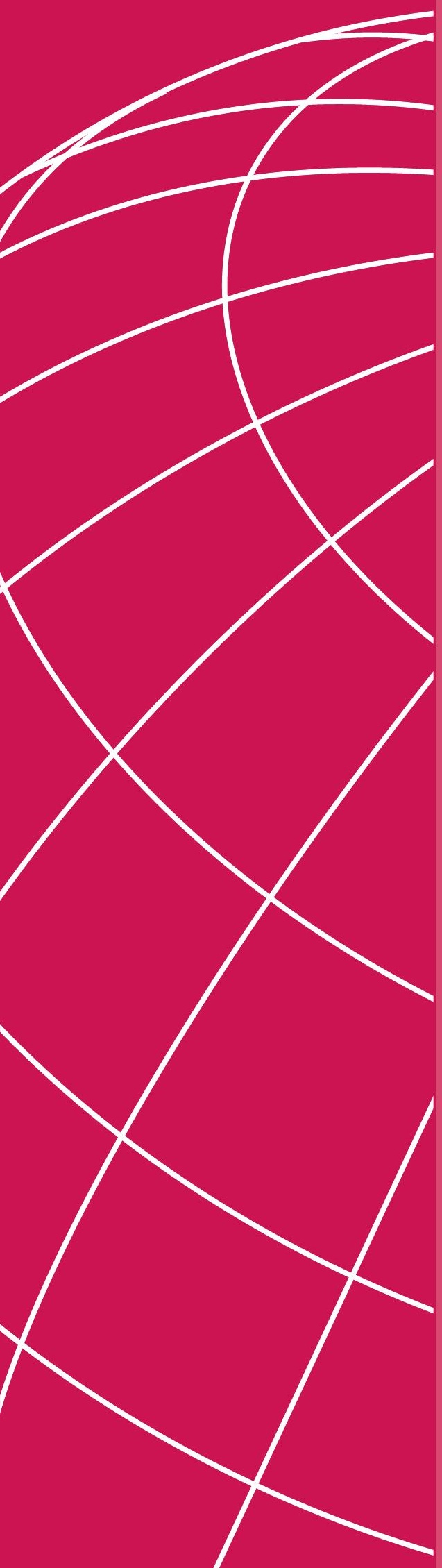

Ash Center Occasional Papers

Tony Saich, Series Editor

\section{What Does General Secretary Xi Jinping Dream About?}

\author{
Tony Saich \\ Harvard Kennedy School
}

\section{August 2017}

Ash Center for Democratic Governance and Innovation Harvard Kennedy School 


\section{Ash Center Occasional Papers Series \\ Series Editor Tony Saich \\ Deputy Editor Jessica Engelman}

The Roy and Lila Ash Center for Democratic Governance and Innovation advances excellence and innovation in governance and public policy through research, education, and public discussion. The Ford Foundation is a founding donor of the Center. Additional information about the Ash Center is available at www.ash.harvard.edu.

This research paper is one in a series funded by the Ash Center for Democratic Governance and Innovation at Harvard University's John F. Kennedy School of Government. The views expressed in the Ash Center Occasional Papers Series are those of the author(s) and do not necessarily reflect those of the John F. Kennedy School of Government or of Harvard University. The papers in this series are intended to elicit feedback and to encourage debate on important public policy challenges.

This paper is copyrighted by the author(s). It cannot be reproduced or reused without permission. 
Ash Center Occasional Papers

Tony Saich, Series Editor

\section{What Does General Secretary Xi Jinping Dream About?}

Tony Saich

Harvard Kennedy School

August 2017

Ash Center for Democratic Governance and Innovation

Harvard Kennedy School 



\section{Executive Summary}

This analysis argues that the period of easy reforms in China has ended, and the time of difficult reforms that touch core political interests has begun. The resulting challenges facing the Chinese Communist Party (CCP) general secretary Xi Jinping when he is confirmed for another five-year-term span political, economic, and international spheres. This leadership must both maintain a domestic focus to strengthen economic growth and avoid the "middle-income trap," while also engaging in a host of regional and global actions to cement China's position on the world stage. Internally, Xi has consolidated significant political power, and this has created significant tension among vested interests and competing centers of influence. Externally, for the first time in several centuries, the largest economy in the world is not Western and will be under a leadership that does not share the same consensual values and political structures as those in the West. Xi has outlined several priorities, including: increased CCP control over state and society; the promotion of traditional Chinese culture; the importance of Marxism as a guiding principle; historical revisionism and censorship; the promotion of nationalism; and the pursuit of an aggressive national anti-corruption campaign. Given these goals and sets of challenges, the outcome in China is uncertain and there exist a range of possible scenarios.

The most attractive for the West would be an increase in social diversity and an accommodation with society to form a new social compact. However, it is difficult to see what would cause the current elite willingly to reject the existing beneficial system. A more unpredictable outcome would be chaotic pluralization in which democracy is not entrenched and elites and their families continue to benefit from their political connections to privatize public wealth. An alternative over the short to medium term would be the continuation of the fluctuation of soft and harder authoritarianism that would make bold initiatives unlikely. Rarely does a transition occur during a period of economic growth and is more likely to occur with the system under stress. As a result, the emergence of an illiberal democracy would be quite plausible under this final scenario. 



\section{Contents}

What Does General Secretary Xi Jinping Dream About? . . . . . . . . . . . . 1

Xi Jinping —The "Core" of the CCP Leadership $\ldots \ldots \ldots \ldots \ldots \ldots \ldots \ldots \ldots \ldots \ldots \ldots \ldots \ldots$

Policy Priorities $\ldots \ldots \ldots \ldots \ldots \ldots \ldots \ldots \ldots \ldots \ldots \ldots \ldots \ldots \ldots \ldots \ldots \ldots$

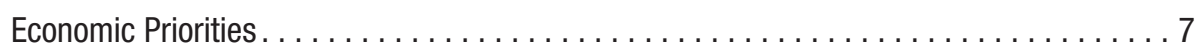

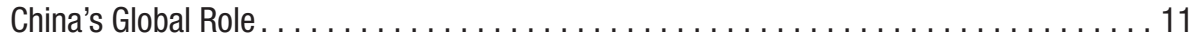

Can Xi's Dream Come True? ..................................... 14

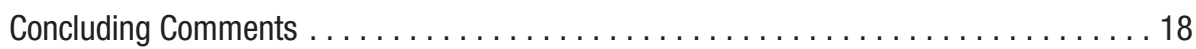

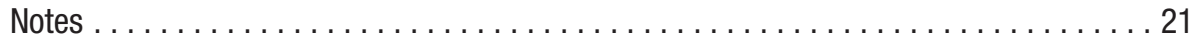





\section{What Does General Secretary Xi Jinping Dream About?}

By the end of 2017, Xi Jinping will have been confirmed as general secretary of the Chinese Communist Party (CCP) for another five-year term. He has come a long way since he was first appointed in November 2012, accumulating and consolidating power swiftly and dominating the political discourse. On assuming power, Xi clearly felt that the challenges facing China were so severe that drastic measures were required. Politics had to take preference over economics and there was the need for a fundamental shift in the development strategy. To meet his objectives, a disciplined, unified party was crucial to push through the next phase of reforms. The critical questions are whether Xi will be able or willing to use this accumulated power effectively and to what purpose. Since the death of Deng Xiaoping (February 1997), each succeeding leader has enjoyed a reduced level of authority as the system settled into one of collective leadership. Xi has reversed this trend.

At a simplistic level, Xi's overriding objective is to maintain $\mathrm{CCP}$ rule but this does not tell us very much. Again, the question arises as to what is he going to do? Minzer argues that, in 2012, politics appeared frozen with economic and institutional reform seemingly frustrated by the vested interests that dominated the CCP. ${ }^{1}$ In significant respects, Xi Jinping has broken with the existing norms and rules that saw senior party officials dividing power among themselves and sustaining elite stability through a balance of power between the different groups. Below, we look at Xi's dream with respect to politics, economics, and China's global role and provide an initial assessment on how realizable the dream may be.

The new leadership that will be selected in late-2017 together with Xi will face a set of daunting challenges to maintain stable economic growth and to cement China's position within the global and regional community. Domestically, China needs reform to ensure that it can avoid falling into the "middle-income trap." China's own leaders admit that the economic development model that has proved successful in the past is no longer suitable as the nation attempts to shift to consumer-led growth and higher-quality production. The nature of China's growth has created severe pollution, not only for air quality but also even more importantly for water and soil. In addition, during the reform years (1978-present), China has gone from being one of the most equal countries in Asia to one of the most unequal. These issues have caused periodic unrest and certainly pollution has been of concern to the growing, urban middle class. Add to this the task of integrating several 
hundred million people into new and old urban environments, and the domestic challenges are indeed daunting.

Externally, China's new leadership will also have to make significant decisions that will define the nation's place in the world. Under President Trump, the US administration would appear to be withdrawing from its previous role within the region and leadership with respect to global challenges such as climate change. The new leaders will have to decide to what extent China may wish to fill this growing leadership void. Whether its leaders acknowledge it or not, China's increasing economic power and associated influence mean that it is involved in the internal affairs of other countries. This will increase as the "One Belt One Road" (OBOR) program gets up and running and with the expansion of the Asia Infrastructure Investment Bank (AIIB). In addition, there are very specific challenges that derive from the nuclear development of North Korea, how China will deal with different perceptions of its territorial claims in the East and South China Seas, and how to manage the US-China relationship under an inconsistent President Trump. Last but not least, with the US withdrawing from the Trans-Pacific Partnership (TPP), the question arises about the extent to which the new leadership will promote the Regional Comprehensive Economic Partnership (RCEP) and can fill the void and determine the norms for trade and investment in the Asia region.

\section{Xi Jinping-The "Core" of the CCP Leadership}

Xi Jinping has consolidated his power over the last five years since his appointment as general secretary at the 18th Party Congress (November 2012). Potential rivals in the party apparatus such as Zhou Yongkang and those in the military such as Guo Boxing have been arrested and their influence eliminated. Most recently, in the run-up to the Congress, Chongqing party secretary, Sun Zhengcai, was removed from his post amid accusations of improper conduct. ${ }^{2} \mathrm{Xi}$ has taken over as head of the key party leading groups dealing with economic, financial, and international affairs. Xi's support from the party hierarchy was surprising initially because when elections were held for the 15th Party Congress (1997), he received the lowest vote among the incoming alternate members of the CCP Central Committee (CC), in part as a protest against the elevation of "princelings" (the children of high-ranking officials). As the preeminent "princeling," he now dominates the party and the central decision-making apparatus to an extent unprecedented since Mao Zedong. His pre-selection image as a 
reliable troubleshooter was enhanced in February 2008 when he successfully took on oversight of the 2008 Summer Olympic Games from former Beijing Municipality Party Secretary Liu Qi. As a result, Xi was charged with overseeing the events for the 60th anniversary of the founding of the People's Republic of China.

In the run-up to the 19th Party Congress (October/November 2017), five pivotal events have made clear Xi's preeminence in the system and attest not only to his continuation as general secretary but also to the fact that he will have a strong say over appointments of members of the Politburo and its Standing Committee. Four members out of seven of the Standing Committee will step down and possibly five, while a further six members of the 25-person Politburo are likely to be replaced.

1. At the Sixth Plenum of the 18th CCP CC (October 2016), Xi was named as the "core" of the party leadership. This is an important designation in the Chinese system, indicating his dominance in the political hierarchy. Since this announcement, there has been a steady stream of military and civilian leaders who have all pledged allegiance to Xi. It places him in a direct line of leadership following Mao Zedong, Deng Xiaoping, and Jiang Zemin. It is noticeable that his predecessor, Hu Jintao, was not awarded this appellation. It marks a step back from the more collective decisionmaking style and process that marked the $\mathrm{Hu}$ and Wen Jiabao years (2002-2012) to one with a preeminent leader at the core, the "chairman of everything."

2. In January 2017, the Chinese press published comments of Xi's from that Plenum in which he accused five senior members of the party of having engaged in "political conspiracies." This moved beyond the earlier accusations that the five were "greedy financially" and "corrupt in their lifestyles." The five are: Zhou Yongkang (Politburo Standing Committee member and in charge of law and order), Bo Xilai (Chongqing party secretary and Politburo member), Guo Boxiong (vice-chair of the Central Military Commission and Politburo member), Xu Caihou (vice-chair of the Central Military Commission and Politburo member), and Ling Jihua (member of the Central Secretariat and said to be close to Hu Jintao). The publication of these comments served as a warning to others in the party who might think of challenging him and served as an expression of his confidence in the strength of his position.

3. The National People's Congress meeting in March 2017 was noticeable for the dominance of $\mathrm{Xi}$ over proceedings rather than that of the premier, 
Li Keqiang. This is a government meeting but the CCP received some 30 mentions, more than at any time since reforms began in the late-1970s. Xi, himself, was mentioned eight times while the "core" was mentioned 11 times. ${ }^{4}$ Given that the work report outlines economic objectives, it is noteworthy that the economy was mentioned 64 times as opposed to around 80 in previous reports. This reflects Xi's preference for dominance of the party over state and society.

4. In early 2015, the party began to promote Xi Jinping's policy slogan of the "Four Comprehensives." Each leader needs a slogan that encapsulates his primary contribution to the ideological pantheon and, in all probability, this will be incorporated into the Party Statutes at the Congress. The "Four Comprehensives" are: comprehensively build a moderately prosperous society, deepen reform, govern the nation in accordance with law, and govern strictly the party. While the first three would be familiar to previous party leaders in the reform era, the fourth clearly shows Xi's concern for party dominance and his campaign to control the corruption and lax practices that he sees as having damaged the party's reputation in recent years.

5. In the immediate build-up to the Congress, Xi has been consolidating his position by removing rivals and promoting allies. The most noticeable is the removal of Chongqing party secretary, Sun Zhengcai, and his replacement with Xi associate, Chen Min'er. Sun had been considered a potential future general secretary of the CCP. Earlier in May, 2017, another Xi acolyte, Cai Qi, was moved from the position of mayor of Beijing to party secretary.

\section{Policy Priorities}

It is evident that the majority of the party leadership felt that $\mathrm{Xi}$ was a trustworthy pair of hands who would ensure continued party rule and maintain its preeminent position, while restoring its credibility and support among the population at large. It was up to $\mathrm{Xi}$ and the new leadership to find a new basis for legitimacy that combined both traditional mechanisms and new methods.

Xi clearly decided that for the party to remain in control, he needed to regain control over the apparatus and be willing to prioritize political issues over the continued restructuring of the economy. Ideally, he would have liked the anti-corruption campaign and economic reform to go hand in hand. Cleaning up the image of the CCP was crucial if the party was to retain its grip on power. He and his colleagues have centralized power and decision making as 
much as possible with the result that Xi has greater formal control over the policymaking apparatus than did his predecessors. He does not trust government or society to carry out his reform ambitions. This has advantages, but also drawbacks. Many complain of a paralysis within government and the party as local officials may decide it is safer to do nothing rather than approve investment or other decisions that might subsequently lead to accusations of misuse of power.

The reform proposals laid out during the Third Plenum of the 18th CCP CC (November 2013) were wide ranging and promised progress on a vast array of areas. It has been impossible to deliver on all of them. Thus, the new leadership appointed at the 19th Party Congress will have to decide on which specific policies are crucial to push ahead with and which can be left aside until a later date. Failure to decide on priorities will entrap the leadership in too many policy fights, dissipate energy, and lead to possible frustration among the populace that too much has been promised with little delivered. The leadership has a clear set of policy priorities for politics, economics, and international affairs that comprise what Xi terms the "China Dream" and the "rejuvenation of the Chinese nation." $\mathrm{Xi}$ and his supporters believe that the CCP is the best organization to push ahead with reforms and to maintain stability. There is a seven-part political strategy:

a) To ensure that the CCP exerts as extensive control over state and society as is feasible and that mechanisms have been developed to oversee effectively new realms such as social media and nongovernmental organizations (NGOs). Xi has made it clear that complete obedience to the party is expected not just from party members but from other members of society. Given, of course, Xi's dominance of the party, in practice this means absolute obedience to himself. To meet this objective, there have been new regulations to tighten control over new social media, vehicles for expression have been limited, and human rights lawyers persecuted. In February 2016, when visiting three top media institutions, Xi stated that editors and reporters must pledge absolute loyalty to the CCP and closely follow its leadership in "thought, politics and action." In December 2016, he delivered a similar message to the nation's schools and universities. Xi claimed that adherence to the party's leadership was essential and that universities should be built into "strongholds that adhere to party leadership." Recently, inspectors have been sent to China's top universities to insure that teachers are not making "improper" remarks in class. Tough restrictions have been placed around foreign NGOs operating in China, while the 
new Charity Law seeks to control the flow of new wealth. The intention not only is to regulate the sector but also to encourage more giving by the wealthy to sectors prioritized by the $\mathrm{CCP}$, while restricting giving to advocacy-based projects. The new framework loosens the requirements for registration but tightens subsequent oversight and enhances party control.?

b) The promotion of traditional Chinese culture. With the talk of moral decay in China and the lingering influence of what is termed "Western liberal values," the leadership has turned to a selective interpretation of traditional culture (especially Confucianism) to bolster its appeal to socialism and to portray the CCP (not the Kuomintang on Taiwan) as the genuine inheritors of the imperial past. Xi has noted that the CCP is the "successor to and promoter of fine traditional Chinese culture." This is remarkable as when the CCP took power in 1949, and especially during the Cultural Revolution (1966-69), it portrayed itself as representing a radical break with the past.

c) At the same time, the leadership has stressed the importance of Marxism as a guide to action for party members. In December 2013, Xi ordered all party members to study Marxist philosophy as the theories still had a "strong vitality and serve as powerful arms of thought for guiding communists to make progress." On the 95th anniversary of the founding of the CCP, Xi called on party members not to "betray or abandon" Marxism. This was part of the efforts to shift party members from obsessions with GDP growth and compiling individual wealth.

d) As a child of one of the founders of the People's Republic of China, Xi is a proud member of the achievements of the CCP and has criticized those who have sought to undermine its image and separate out the years of Mao Zedong's rule from those of the reform era. This has led to a clampdown on critical research and the publication of academic accounts that have sought to minimize the damage caused by movements such as the "Great Leap Forward" (1958-60). There have been attacks on domestic and international historians who have promoted "historical nihilism," that is, those who have not followed the official account of Chinese party history.

e) There have been attempts to exert greater control over society, to restrict the extent of intellectual criticism, and to limit the influence of "Western theories and ideas." An internal document from April 2013 criticized a range of ideas that were current such as: constitutional democracy, universal values, neoliberalism, and historical nihilism. ${ }^{10}$

f) What has been very noticeable is that after assuming power, Xi launched a movement for officials to practice more frugal behavior (encapsulated in the slogan "four dishes and a soup") and the strongest campaign in 
recent memory against corruption within party and government ranks. This started before the leadership turnover when the removal of Chongqing party secretary Bo Xilai paved the way for Xi's ascendancy. Under the slogan "catching tigers and flies," the campaign has broadened beyond what some observers saw as a factional struggle to net at least one senior leader in every provincial unit in China. Over 120 senior officials have been arrested, including five national leaders with the biggest "tiger" caught being Zhou Yongkang, a former member of the Politburo Standing Committee and overseer of the domestic security system. However, it was reported in January 2017 that the number of officials turned over to the court had dropped by 20 percent to around $11,000 .{ }^{11}$ The campaign is viewed as crucial to efforts to ensure that the CCP will function effectively and to restore the public's faith in the organization. $\mathrm{Xi}$, with the enthusiastic support of his Standing Committee ally Wang Qishan, wants to use the momentum to attack corrupt behavior within the elite of those who are not necessarily factional enemies. This is a dangerous path to follow and may cause a backlash within the party that could weaken Xi's position and undermine other aspects of his intended reform program. The post-19th Party Congress top leadership will have to decide whether to accept this focus on corruption and the centralization of power in Xi's own hands. Given his apparent control over the apparatus in advance of the Congress, it seems most likely that those chosen will follow his lead.

g) The promotion of nationalism has accompanied the revival of traditional culture to bolster regime legitimacy. Key to this process has been to identify the nation with the party to make criticism of party policy unpatriotic. This has been accompanied by a more assertive posture over territorial issues.

\section{Economic Priorities}

Clearly, the economic model of development that had produced strong growth for more than three decades has run its course. It is difficult to see state investment rising further, neither is an increase in exports likely. This calls for greater reliance on consumption as a driver of growth. Liu Shijin, a former vice-minister of the Development Research Center of the State Council has commented, "The end has come to the period of purely "quantitative expansion' and of extensive cultivation for meagre returns." The new economic priorities were laid out most explicitly at the December 2013 Third Plenum of the 18th CCP CC. What is most remarkable about the priorities 
is that they are almost identical to those put forward in 2002-03 when $\mathrm{Hu}$ Jintao and Wen Jiabao took over power. This shows how difficult it is to complete such a transition.

While most foreign observers focused on the stress on the role of the market, the document also contains a clear emphasis on the role of the state-owned enterprises (SOEs) and state engagement in economic development. This has led some observers to refer to the approach as "state capitalism," while the Chinese leadership refer to it as "socialism with Chinese characteristics" and more recently as "supply-side economic reforms." Certainly, the current Chinese leadership have developed an industrial policy and this policy is designed to ensure that the party retains control over key sectors of the domestic economy as well as having greater influence over investment outside of China. There is no doubt that gradually there has been greater recognition of the role of the market in producing efficiency gains and more effective use of investment funds. We can see the increasing emphasis on a positive role for the market in the sequential Five-Year Plans, culminating in the 12th Plan (2011-2015) that stated the necessity of giving "full play to the socialist mechanism as well as the market in terms of allocating resources." In March 2013, Premier Li Keqiang stated that "the market is the creator of social wealth and the wellspring of self-sustaining economic development."

Despite mention of the market, the current leadership and those likely to take over at the 19th Party Congress see continued state guidance over economic development as crucial. First, there has been a consistent view that SOE reform should not result in wholesale privatization but rather in the development of national champions along the lines of industries in Japan and South Korea. This is also true for the approach of former Premier Zhu Rongji who sought to establish a stronger industrial policy and state oversight combined with the promotion of stronger market forces.

Further strengthening the role of the state sector in the economy was the launch of the policy of "indigenous innovation" in 2006. This focused on industries such as new-energy vehicles, high-end equipment manufacturing, biotechnology, and information technology. This retention of state dominance over the domestic economy is also reflected in Chinese overseas investment. These major industries and pillars were part and parcel of the "going out" strategy that was to increase overseas investments and the expansion of the globalization of Chinese enterprises. The state clearly intends to play a major role in Chinese overseas investment and to control more effectively the 
buying spree and mergers and acquisitions of recent years. With the slowing of the domestic economy, both private enterprises and SOEs looked to invest abroad, on occasion buying at inflated prices. This created fears of capital flight. Temporary limits were placed on the scale of overseas transactions with those over $\$ 10$ billion generally banned and over $\$ 1$ billion if the project fell outside of the core focus of the business. That the state will take a more active role is shown by the establishment of the AIIB and the large OBOR program. These projects, which are designed to promote China's international interests, will clearly favor major state-owned enterprises; indeed, one purpose is to enable them to export excess capacity and set up production facilities overseas.

There are eight key components of the strategy:

a) The Chinese leadership has announced the "New Normal" for the economy. This means that they are striving for more sustainable and balanced growth. The days of double-digit growth are over and the expectation is for GDP growth in 2017 of around 6.5 percent, the slowest growth rate in 26 years.

b) Most recently, the phrase "New Normal" has been eclipsed by that of "supply-side economic (or structural) reform." This should not be confused with President Reagan's policies of the 1980s. The main elements are: cutting excess capacity, especially in steel production (Chinese exports have roiled global markets and upset President Trump); closing down some of the "zombie" SOEs, but subsidizing a smaller number of favored and often inefficient industries; and tax breaks for new industries such as electric vehicles and eco-friendly agriculture. It reflects Xi Jinping's push for stronger central control by the CCP over the economy.

c) The promotion of consumption as the primary driver of economic growth. As noted, the two previous main drivers of growth, state-led investment and export-led growth, cannot continue to stimulate high growth and, while they will remain major factors, they need to be supplemented by the increase in domestic consumption. This shift will contribute to the lower growth rates moving forward.

d) In turn, this will be aided by a more judicial use of market forces to allocate resources and capital. The Decision of the 3rd Plenum of the 18th CCP CC noted that the prices of water, oil, gas, electricity, transportation, and telecommunications would all be set by the market. However, more recently, the National Development and Reform Commission has reasserted its production targets for key products. 
e) Reform of the state-owned sector was to be strengthened but, in terms of market pricing, the Decision made no mention of breaking up the SOE monopolies that dominate these sectors. Subsequent reforms have not progressed far and the political power of the sector remains strong. It is also the case that the CCP leadership does not necessarily mean that SOE reform should lead to large-scale privatization or liberalization but rather to allow them to contribute to the CCP's political standing more effectively.

f) Financial sector reform. Many of the key leaders from Zhu Rongji's team have been kept in place, with the noticeable exception of reform-minded Lou Jiwei who was shifted from minister of finance to be chair of the National Council for Social Security Fund (November 2016). For reforms, it is important that not only those for macroeconomic stability be maintained but also that the sector be used to promote other reforms throughout the real economy. Interest rate liberalization has been pursued and other reforms are intended to move capital to the non-state sector of the economy where returns are higher than in much of the SOE sector. Using the Renminbi for trade settlements is becoming more common but internationalization of the currency remains a long way off.

g) Urbanization. By 2030, policymakers expect there to be a further 310 million new urban inhabitants in China. Urbanization is viewed as a fix to certain policy challenges: reducing income inequality, maintaining the 6.5 percent growth rate, aiding the shift to consumption-driven growth, and providing more effective public goods and services. At the same time, it will present new challenges: economic and social inclusion of migrants, control of pollution, managing expectations of a growing middle class, and deciding on the focus of urban development. Getting the policies right for effective urbanization will be a major challenge for the post-19th Party Congress CCP leadership. Currently, the use of administrative modes of urbanization rather than natural urbanization with the focus on smaller town development may have to be reviewed. This may create problems of matching work opportunities and resources to labor flows. A focus on small town development rather than on extra-large cities will require an estimated 11,000 square kilometers of land in an environment where arable land is already declining precipitously.

h) A critical component for producing sustainable growth is dealing effectively with the tradeoff between economic growth and environmental degradation. At the National People's Congress in March 2014, Premier Li Keqiang declared a war on pollution. Unlike many other challenges (such as inequality, corruption, and monopoly controls), environmental pollution affects all citizens: rich or poor, urban or rural. Environmental 
cleanup will be a long-term process but it will have to be addressed by the post-19th Party Congress top leadership in a way that is reassuring to China's citizens, especially as more of them move into urban centers that, in turn, will create more pollution. It is the one policy issue that is capable of destabilizing CCP rule. Given that the overriding priority of the $\mathrm{CCP}$ is to retain power, combatting pollution may begin to drive policy for good and for bad simultaneously.

\section{China's Global Role}

China's economic rise will change geopolitics and we are seeing a divergence of views about how threatening this might be to traditional US dominance and agenda setting. We are reaching what Mike Lampton has referred to as a "tipping point." ${ }^{2}$ For the first time in a couple of centuries, the largest economy is not Western and will be under a leadership that does not share the same consensual values and political structures as those in the West. This has led some US analysts to suggest that policy should shift from engaging China to being more confrontational and even constraining its rise. ${ }^{13}$ Elements of this infuse the rhetoric of the Trump administration. However, also for the first time, the world's largest economy will not enjoy the highest living standards and still faces considerable challenges moving forward. This gives more succor to those who wish to continue engagement under the belief that it will cause China to be accepting of global norms and practices. ${ }^{14}$

In addition, we are seeing a potentially dangerous bifurcation between an economic Asia within which China is the central player and a security Asia, which is dependent on US military power. ${ }^{15}$ President Trump's decision to abandon the TPP has severed a potential valuable link for the US between the two. This also opens the question of whether China's new leaders will seek to define regional and, perhaps global, trade and investment norms. This may not be as easy for China's new leaders to achieve as some have assumed. Certainly, the US abandoning TPP and not joining AIIB (an Obama administration decision) heralds a decline in US influence in Asia that cannot be replaced by increased military spending. However, it does not mean that China will automatically fill the gap. With respect to trade, TPP reached a general agreement on the standards and rules that would be adopted for a diverse range of economies and included regulations for labor and environmental standards. The Chinese-promoted Regional Comprehensive Economic Partnership, which excludes the US, does not have such an integrated approach and allows members flexibility to choose which commitments to 
adopt. Importantly, it will not help with the market for services, which is growing rapidly in Asia, but remains heavily protected in much of the region. Further, despite the relative decline of the US, it retains a stronger network of alliances than China. That said, China is improving its ties with the Philippines and with Thailand while dominating the Kampuchean and Lao economies and increasingly putting Myanmar in a difficult position. Yet, this and China's actions in the South China Sea have caused concern within the region with some claiming that China is using up its "great reserves of goodwill" and that it is sacrificing long-term objectives and its global interests for short-term objectives. ${ }^{16}$

Powerful countries shape the world and, whether they like it or not, China's new leaders will be forced to take a more proactive stance not just on questions of territorial sovereignty but also on ones of reserve currencies, banking and financial regulations, trade and investment agreements, climate discussions, the provision of public goods, etc. This will present a huge challenge for the new leadership as they have not had extensive experience with negotiations in many of these areas. They will have to come to terms with the fact that the country is a major global player and the global community will expect clearer explanations of its policy intent. The need to focus on their increasingly demanding global agenda may draw their attention away from the necessary focus on their domestic agenda.

Certainly, Xi Jinping is more ambitious in this area than his predecessor $\mathrm{Hu}$ Jintao and has put forward the slogan of the "rejuvenation of the Chinese nation" together with the "China Dream" to project this vision. We can see three key features that have emerged under Xi's leadership and it is clear that Deng Xiaoping's doctrine of "hiding one's capabilities and biding one's time" and as a result keeping a low profile and not claiming leadership has been replaced by Xi's desire to bring about a more active international role. This has involved suggesting that China is willing to step up in global leadership in those areas that the US abdicates from, redressing the relationship with the US and with the Asian region. At a December 2014 Politburo session, Xi noted that China was now embarking on a "new round of opening to the world," emphasizing that China would no longer take a passive role in global economic governance. He stated, "We cannot be a bystander but must be a participant, a leader." There are three key features:

a) It may seem strange to have the president of China as one of the firmest defenders of economic globalization but it is not surprising as his country is 
one of the major beneficiaries. In January 2017 at Davos, Xi Jinping argued that economic integration had furthered human development and improved the lives of millions of people. In Xi's view, economic globalization was the giant ocean from which you could not escape. ${ }^{17} \mathrm{Xi}$ has also stepped up to defend the Paris Agreement on climate change, stating that it must not be allowed to fail. Both these stances could be seen to be a counter to President Trump who supports more protectionist policies and has, on occasion, called climate change a "hoax." That said, both President Xi and Vice-Premier Wang Yang have stated that they do accept the current economic order and the leadership role that the US has played in this order. Under a Trump administration more focused on domestic benefits, it will be interesting to see whether the new Chinese leadership maintain this stance.

b) The formation of a "new type of great power relationship." This has been put forward by Xi to dictate his relationship with the US and while it was rejected by President Obama, Secretary of State Tillerson during his March visit to Beijing seemed to come close to accepting China's main premises. Certainly, China's perceived rise has engendered different responses about how to deal with the evolving situation ranging from tougher containment to trying to find new ways to engage that would entail reforming existing global institutions (IMF and World Bank) and forming frameworks for new global challenges that could be categorized under the headings of global commons, global engagement, and global regulation. Two of the central issues will be the trade imbalance and the threat of North Korea's nuclear programs and how the US and China negotiate these.

c) It has become evident that China is developing a more coherent policy towards Asia. Previously, while its major interests were in Asia, the leadership did not think in regional terms at all. In 2013, Foreign Minister Wang Yi signaled a shift that indicated more attention would be paid to the Asia region and that a "community of common destiny" could be created. ${ }^{18}$ This has entailed carrots and sticks.

The carrot is the range of investments that China is developing for the region. This includes the OBOR project and the establishment of the AIIB. In part, the establishment of these financial institutions is to allow China to export its excess domestic capacity (steel, cement, etc.) to the region but also it provides the opportunity to tie nations throughout the region into China's sphere of influence. The stick relates to questions of sovereignty and China's more aggressive moves in the South China and East China Seas that have created concern among countries such as Japan and Vietnam. In turn, this has caused 
a tightening of security relations with the US. However, the major challenge in the region is that of North Korea's nuclear development and this will test China's leadership capacity. President Trump has made it clear that he feels that China has not done enough to curb North Korea's nuclear development and China's leadership of the Six-Party Talks has not yielded progress. US capacity to pressure North Korea is not strong and neither is its capacity to push China.

\section{Can Xi's Dream Come True?}

$\mathrm{Xi}$ is demonstrably a much stronger leader and more confident than his predecessor, Hu Jintao. Moreover, he has created a vehicle to oversee and push through reforms with the Central Leading Group on Comprehensively Deepening Reforms, which has institutions at all levels of the bureaucracy. However, there are various barriers to meeting the policy objectives. For example, does the document from the Third Plenum of the 18th CCP CC contain too many priorities, encouraging local officials to pick and choose those that suit them most while holding off implementing others? It is still not clear that the tradeoff between economic growth and environmental degradation can be managed effectively.

A clear problem is that the reform program, especially since China entered the WTO in 2001, has created strong vested interests that are favored by maintaining the status quo. This includes many in the state-owned sector as well as central and local officials and their families. With reform in the 1980 s, it was easier to see who would benefit as was also the case in the 1990s when policies launched a free-for-all to exploit state resources to get rich. The current proposed economic reforms would damage these vested interests, while the anti-corruption campaign causes those local officials who $\mathrm{Xi}$ must rely on to be cautious and often inactive.

There are remaining questions about economic growth moving forward and how successful China can be in promoting its external policies. For the economy, one central question that has been debated is whether the slowing of the Chinese economy has ended and can China move beyond the "middle-income trap." In April 2015, then-Minister of Finance Lou Jiwei in a speech at Tsinghua University stated that China had a "50-50 chance" of sliding into the middle-income trap over the next five to 10 years. In his view, avoidance was dependent on pushing ahead with comprehensive reforms. ${ }^{19}$ 
In part, the slowing of the economy is natural as the period of high growth driven by investment is now over. Growth rates have slowed and the main question is whether the nadir has been reached. The work of Perkins and Rawski on economic development in Japan, the Republic of Korea, and Taiwan offers a good indicator. They show that in these three economies, after decades of high-level growth, growth slowed at a similar level of income above $\$ 13,000$ per capita income PPP, never to revive again significantly. ${ }^{20}$ The World Bank estimates China's per capita income PPP to be $\$ 15,535$ in 2016, while the CIA estimates it to be $\$ 14,600$.

There are two aspects that can support continued growth in China. The first is the relationship of sustainable growth to institutional development and the second is whether total factor productivity (TFP) can be maintained or, preferably, improved. Table 1 below shows the relationship between the governance indicators compiled by the World Bank and the income per capita, and how those countries with higher incomes have better governance indicators. David Dollar, former head of the World Bank in China, provides support for this view. ${ }^{21}$ He claims that there is a strong empirical relationship between the quality of institutions and economic growth. Successful development on Taiwan and in Korea is attributed to the nature of the institutions and

Table 1. The Middle Income Trap?

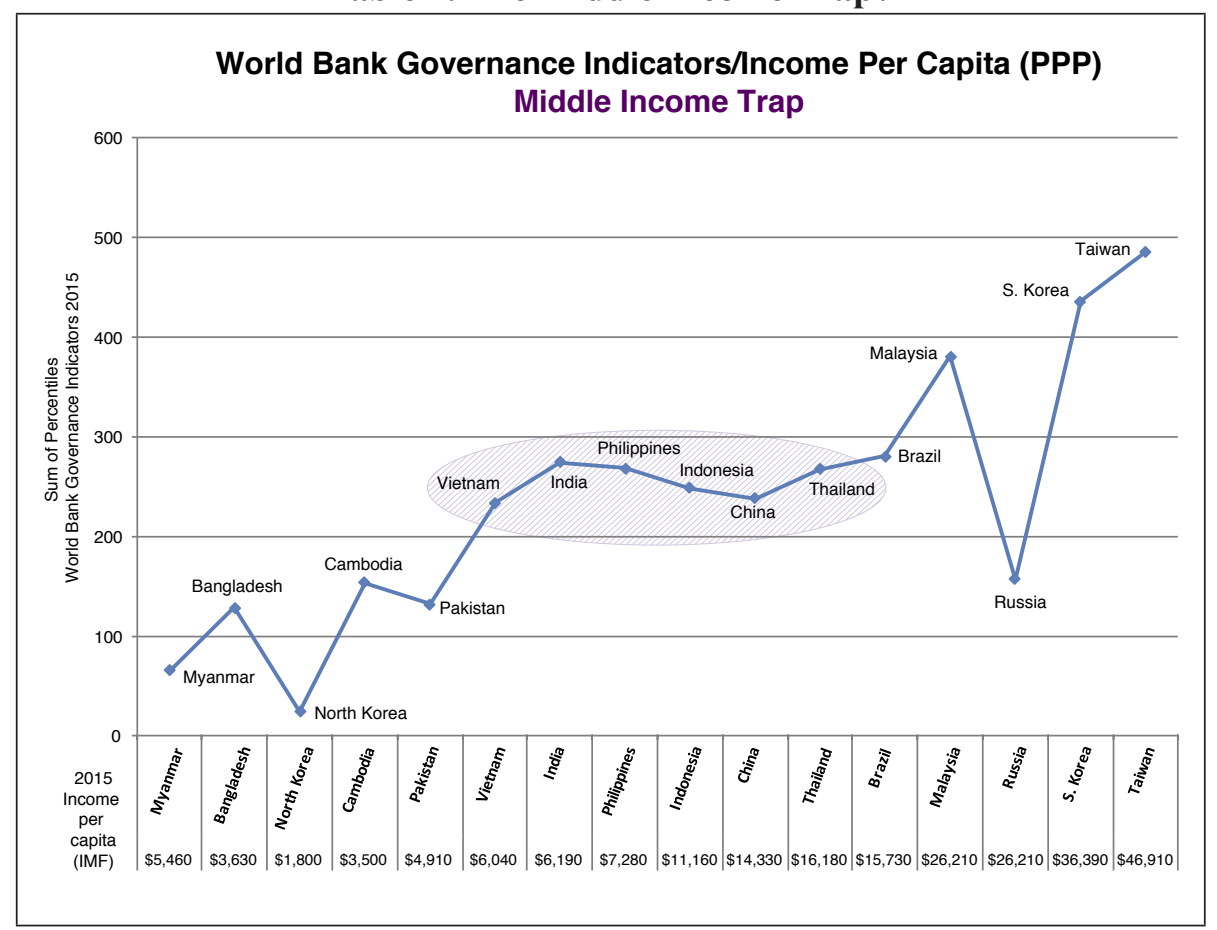


the state interventions. These provided a policy framework for competition, growth, and exports. Dollar notes that countries such as China and Vietnam have good institutions for their current level of economic growth and, consequently, they have been able to attract high levels of foreign direct investment. As incomes rise it becomes more difficult for authoritarian regimes to maintain growth because at this point the economic system needs political and economic institutions that promote competition, innovation, and productivity growth rather than simply accumulating increasing amounts of capital.

Thus, growth will remain at a lower level but just how much it slows will depend on whether TFP can be raised. The demographic dividends that helped push growth since the reforms began have ended with the labor force set to decline. In addition, there are problems with diminishing returns in many sectors in the economy that have an overcapacity, due in large part to the stimulus package launched to help China through the global financial crisis of 2008-09. Rosen and Snyder see 6-percent growth in 2020 as feasible though only if TFP can be raised and investment in capital stock is directed towards more productive assets. ${ }^{22}$ This requires the move from "state allocation to market intermediation"; without this growth could fall to 3 percent or even lower.

In addition to the failure to push ahead with domestic reforms, there will also be external barriers as China's economy and global integration advances further. This will depend not only on the general health of the global economy but also on how countries in the region and other major trading partners such as the US interpret China's growth. There will be currency and trade disputes, the impact of Chinese companies going global, and the impact of OBOR. Here we just touch on briefly the relationship with the US and the potential for OBOR.

In most probability, the meeting between President Trump and President Xi Jinping at Mar-a-Lago (April 2017) marked the high point in the relationship. Trump's hope that China could help significantly to resolve the problem of North Korea's nuclear development was short-lived and this realization is liable to bring other contentious areas in the relationship such as trade and the sovereignty issues in the South China Sea back to the fore. ${ }^{23}$ While both countries might want a denuclearized Korean peninsula, China does not want this at the risk of regime collapse.

With US withdrawal from the Paris Climate Agreement and from economic leadership within the Asia region, the question arises as to whether China 
will take on the mantle. The factors that helped the US exert influence are weakening while China is improving ties through its economic muscle. However, this does not automatically mean that China can assume leadership, even presuming that it wished to do so. Currently, it does not have the network of allies that the US enjoyed and there is concern in the region from some countries about China's territorial claims. As argued above, even on trade, it is not clear that China will set the rules moving forward. The Chinese-led RCEP does not have such an integrated approach as the TPP and does not include strictures for labor and environmental issues. Importantly, unlike TPP, it does not have guidelines for the rapidly growing services sector. If we look at China's trade agreements, in contrast to those of the US, they display a great variation depending on the specifics of the deal and the political relations with the country concerned.

A central component of Xi's dream is the OBOR project, which many national leaders recently came to Beijing to pay homage to. ${ }^{24}$ Although it is one of his highest priorities and certainly the increased investment in infrastructure is welcome, it is difficult to define clearly its scope and the precise role of the funding agencies. ${ }^{25}$ What we know is that substantial interests will shape the program as it moves forward as they attempt to use the prestige and the large amount of state funds to their own advantage. Already, most provinces are repackaging their existing plans to become OBOR projects. ${ }^{26}$ At the center, the program will be driven by the National Development and Reform Commission, the Ministry of Finance, and the Ministry of Commerce, each of which will have different priorities.

To date most of the overseas lending does not go to those 65 countries defined as forming a part of OBOR, the main destinations being Europe, the US, Australia, and Canada. David Dollar has pointed out that being along the belt and road has not yet delivered more investment than is received by other parts of the developing world. ${ }^{27}$ Dollar also notes that China is less risk averse than Western investors. Given that Xi Jinping's reputation is tied to the success of this program, and with the state reasserting control over major outbound investment, riskier projects may be taken on to meet political objectives. This, despite the continual stress that projects must be financially viable.

Clearly, there is a geopolitical objective to OBOR and the drive to create and maintain secure energy supplies, but it also has explicit objectives that are intended to help with China's domestic economic challenges. Justin Lin 
was an early enthusiast who saw both economic benefits and an opportunity for China to take on a global role and provide an alternative to TPP and US actions. ${ }^{28}$ For the domestic economic rationale, Peter Cai has pointed out that it will form part of China's strategy to reduce regional inequality by focusing significant funds on provinces such as Xinjiang, help reduce the enormous production overcapacity that resulted from the stimulus package, and help China set industry standards that will form a part of China's "Made in China 2025 " strategy. ${ }^{29}$

The challenges and problems confronting the development of OBOR are reasonably clear. As noted, the association of OBOR with General Secretary $\mathrm{Xi}$ might encourage investors to take on riskier projects than the economic potential might suggest. The question arises as to whether there are enough financially feasible projects to go around? The problem of contributing to China's debt is raised by the fact that many of the core countries have poor credit ratings and are not stable political environments. Last but not least, the question arises as to whether Russia will accept the growing influence of China in what it has viewed traditionally as its own backyard?

\section{Concluding Comments}

The analysis above shows that realizing General Secretary Xi's dream faces significant challenges across all three areas: political, economic, and global outreach. It does not mean that it is impossible but hard work will be necessary. On the political front, is the concentration of power with the "chairman of everything" what China needs at its current stage of development? Can China develop the institutions necessary to provide transparency of government action and feedback loops for its citizens? Can the institutions be developed that will facilitate competition and innovation to help China move out of the middle-income trap and can the vested interests be overcome to enable investment to flow to the more productive parts of the economy rather than inefficient state-owned enterprises? On the international front, will China become a responsible stakeholder that helps set global norms moving forward and become a key player in providing global public goods?

The problem is that the easy parts of reform are done and now the more difficult components remain that touch on the core of party power. The outcome is uncertain and we need to prepare for a range of possible scenarios. The most attractive for the West would be for the leadership to respond to 
the increasing diversity in society and the rising protests to form an accommodation with society and try to form a new social compact. However, it is difficult to see what would cause the current elite willingly to reject the existing beneficial system. A more unpredictable outcome would be a "Yeltsin scenario," with chaotic pluralization where democracy is not entrenched and elites and their families continue to benefit from their political connections to privatize public wealth.

An alternative over the short to medium term would be the continuation of the fluctuation of soft and harder authoritarianism that would make bold initiatives unlikely. Even if Xi gets the leadership group he wants after the 19th Party Congress, it will be difficult to push through the kind of reforms that will dislodge the current beneficiaries. Political transitions are rare and there is no necessary reason why China might follow its East Asian neighbors into a robust democracy. Rarely does a transition occur during a period of economic growth and is more likely to occur with the system under stress. The emergence of an illiberal democracy would be quite plausible under this scenario. It may resemble some of the Central Asian states or Russia under Putin where the authoritarian undertones remain strong. There would be a dominant executive with a weak legislature and a fragmented civil society overseen by a strong domestic security apparatus and military. The leadership would stress the fear of social chaos to keep the middle class supportive with a stronger nationalism to cement patriotic cohesion. A not encouraging but quite likely future outcome. 



\section{Notes}

1. Carl Minzer, "China After the Reform Era," Journal of Democracy, vol. 26, no.3 (July 2015): 129-43.

2. See, Chris Buckley, "Former Political Star in China Is Under Party Investigation," New York Times, July 24, 2017.

3. "Chinese president accuses fallen top officials of "political conspiracies," South China Morning Post, January 2, 2017.

4. "Word Count: Chinese State of the Nation Speech All About the Party," China Real Time Report, The Wall Street Journal, March 5, 2017.

5. "Xi Jinping asks for 'absolute loyalty' from Chinese state media," The Guardian, February 19, 2016.

6. "Xi calls for strengthening ideological work in colleges," December 8, 2016, accessed at http://news.xinhuanet.com/english/2016-12/09/c_135891337.htm on July 8, 2017.

7. See Tony Saich, "What Does Philanthropy Look Like Among China's New Rich?" in The China Questions (Cambridge: Harvard University Press, forthcoming).

8 . This was in his speech on the 2565th anniversary of the birth of Confucius.

9. "Xi Jinping pledges return to Marxist roots for China's communists," The Financial Times, July 1, 2016.

10. "Communiqué on the Current State of the Ideological Sphere," Notice from the CCP CC's General Office. April 22, 2013. Chinese original with author.

11. "China corruption prosecutions drop for first time in five years," The Financial Times, January 25, 2017.

12. David M. Lampton, "A Tipping Point in US-China Relations Is Upon Us," speech at the conference "China Reform: Opportunities and Challenges," May 6-7, 2015, dated May 11, 2015, accessed at https://www.uscnpm.org/blog/2015/0 5/11/a-tipping-point-in-u-s-china-relations-is-upon-us-part-i/ on July 8, 2017.

13. Robert D. Blackwill and Ashley J. Tellis, Revising US Grand Strategy Toward China, Council on Foreign Relations, special report No. 72, March 2015.

14. Kevin Rudd, US-China 21. The Future of U.S.-China Relations Under Xi Jinping. Toward a New Framework of Constructive Realism for a Common Purpose. Harvard Kennedy School, April 2015.

15. Evan A. Feigenbaum and Robert A. Manning, "A Tale of Two Asias" in Foreign Policy, October 31, 2012.

16. Kishore Mahbubani, “ASEAN still critical catalyst for China’s future," East Asian Forum, October-December 2016.

17. Xi Jinping, "Jointly Shoulder Responsibility of Our Times, Promote Global Growth,” January 17, 2017, accessed at https://www.america.cgtn.com/2017/01 /17/full-text-of-xi-jinping-keynote-at-the-world-economic-forum.

18. See, for example, "Foreign minister calls on China, ASEAN to enhance political trust," July 25, 2016 accessed at http://english.gov.cn/state_council/ministries /2016/07/25/content_281475401180259.htm on July 8, 2017. 
19. "Top China official's criticism of labour policy sparks controversy," South China Morning Post, May 3, 2015.

20. Dwight H. Perkins and Thomas G. Rawski, "Forecasting China's Economic Growth to 2025," in Loren Brandt and Thomas G. Rawski (eds.), China's Great Economic Transformation (New York: Cambridge University Press, 2008).

21. David Dollar, "What institutions do Asian countries need to keep growing?" in East Asia Forum, May 31, 2015.

22. Daniel H. Rosen and Anna Snyder, "China's Outlook-Now and in 2020," August 8, 2014, accessed at http://rhg.com/notes/chinas-outlook-now-and-in-2020 on July 9, 2017.

23. Indeed, it seems that their interactions at the G-20 summit (July 2017) did not go so well with disagreements over trade and especially "steel-dumping." "“Face like thunder': how the mood soured at Donald Trump's first summit," The Guardian, July 9, 2017.

24. Some 28 heads of state were in attendance. "China is about to hold a giant meeting on spending billions to reshape the world," CNBC, May 10, 2017, accessed at http://www.cnbc.com/2017/05/10/china-is-about-to-hold-a-giant -meeting-on-spending-billions-to-reshape-the-world.html on July 9, 2017.

25. Formally, it covers 65 countries with one-third of global GDP and 60 percent of the world's population. On the geographic reach see the discussions over whether Africa forms a part of OBOR or not. Despite the creation of the Silk Road Fund and the existence of the AIIB, most funding still seems to come through the China Development Bank and the Export-Import Bank. It has been named as one of three major national strategies and enjoys an entire chapter in the latest five-year plan (2015-2020).

26. On recent trips to China, I was asked to join various OBOR research programs as it would be easy to get state funding.

27. David Dollar, "Yes, China is investing globally — but not so much in its belt and road initiative," May 8, 2017, accessed at https://www.brookings.edu/blog/order -from-chaos/2017/05/08/yes-china-is-investing-globally-but-not-so-much-in-its -belt-and-road-initiative/.

28. Among various pieces see Justin Yifu Lin, "China’s Silk Road Vision," January 21, 2016, Project Syndicate.

29. Peter Cai, "Understanding China's Belt and Road Initiative," March 22, 2017, available at https://www.lowyinstitute.org/publications/understanding-belt-and -road-initiative. 
Ash Center for Democratic Governance and Innovation Harvard Kennedy School

79 John F. Kennedy Street

Cambridge, Massachusetts 02138

T 617.495 .0557

F 617.495.4948

www.ash.harvard.edu 